Article

\title{
Forest Canopy Can Efficiently Filter Trace Metals from Deposited Precipitation in a Sub-Alpine Spruce Plantation
}

\author{
Siyi Tan, Hairong Zhao, Wanqin Yang, Bo Tan, Kai Yue, Yu Zhang, Fuzhong Wu, Xiangyin Ni * \\ Long-term*Research Station of Alpine Forest Ecosystems, Provincial Key Laboratory of Ecological Forestry \\ Engineering, Institute of Ecology and Forestry, Sichuan Agricultural University, 211 Huimin Road, Wenjiang \\ District, Chengdu 611130, China \\ * Correspondence: nixy@sicau.edu.cn; Tel. :86-28-86290957; Fax: 86-28-86290957.
}

\begin{abstract}
Trace metals can enter some natural regions with low human disturbance from atmospheric circulation, but little information is available regarding how the canopy can retained trace metals. Therefore, a representative sub-alpine spruce plantation was selected to investigate the net throughfall fluxes of eight trace metals ( $\mathrm{Fe}, \mathrm{Mn}, \mathrm{Cu}, \mathrm{Zn}, \mathrm{Al}, \mathrm{Pb}, \mathrm{Cd}$ and $\mathrm{Cr}$ ) of closed canopy and gap-edge canopy from August 2015 to July 2016. Over a one-year observational period, the annual fluxes of $\mathrm{Al}, \mathrm{Zn}, \mathrm{Fe}, \mathrm{Mn}, \mathrm{Cu}, \mathrm{Cd}, \mathrm{Cr}$ and $\mathrm{Pb}$ were $7.29 \mathrm{~kg} \cdot \mathrm{ha}^{-1}, 2.30 \mathrm{~kg} \cdot \mathrm{ha}^{-1}, 7.02 \mathrm{~kg} \cdot \mathrm{ha}^{-1}, 0.16$ $\mathrm{kg} \cdot \mathrm{ha}^{-1}, 0.19 \mathrm{~kg} \cdot \mathrm{ha}^{-1}, 0.06 \mathrm{~kg} \cdot \mathrm{ha}^{-1}, 0.56 \mathrm{~kg} \cdot \mathrm{ha}^{-1}$ and $0.24 \mathrm{~kg} \cdot \mathrm{ha}^{-1}$, respectively, in the deposited precipitation. The annual net throughfall fluxes of these trace metals were $1.73 \mathrm{~kg} \cdot \mathrm{ha}^{-1}, 0.9 \mathrm{~kg} \cdot \mathrm{ha}^{-1}$, $1.68 \mathrm{~kg} \cdot \mathrm{ha}^{-1},-0.032 \mathrm{~kg} \cdot \mathrm{ha}^{-1}, 0.04 \mathrm{~kg} \cdot \mathrm{ha}^{-1}, 0.018 \mathrm{~kg} \cdot \mathrm{ha}^{-1}, 0.093 \mathrm{~kg} \cdot \mathrm{ha}^{-1}$ and $0.087 \mathrm{~kg} \cdot \mathrm{ha}^{-1}$, respectively, in the gap-edge canopy and $-1.6 \mathrm{~kg} \cdot \mathrm{ha}^{-1}, 1.13 \mathrm{~kg} \cdot \mathrm{ha}^{-1}, 1.65 \mathrm{~kg} \cdot \mathrm{ha}^{-1},-0.10 \mathrm{~kg} \cdot \mathrm{ha}^{-1}, 0.05 \mathrm{~kg} \cdot \mathrm{ha}^{-1}, 0.03 \mathrm{~kg} \cdot \mathrm{ha}^{-1}$, $0.26 \mathrm{~kg} \cdot \mathrm{ha}^{-1}$ and $0.15 \mathrm{~kg} \cdot \mathrm{ha}^{-1}$, respectively, in the closed canopy. The closed canopy displayed a greater filter effect on the trace metals from precipitation than did the gap-edge canopy in the sub-alpine forest. In the rainy season, the net filtering ratio of trace metals ranged from $-66 \%-89 \%$ in the closed canopy and from $-52 \%$ to $25 \%$ in the gap-edge canopy. However, the net filtering ratio of all trace metals was greater than $50 \%$ in the closed canopy in the snowy season. Therefore, the results suggested that the most trace metals moving through the forest canopy are taken up rather than by rainfall leaching; moreover, the closed canopy can efficiently take up trace metals in the snowy season.
\end{abstract}

Keywords: Forest hydrology; Canopy filtering; trace metal; throughfall; gap edge canopy; closed canopy

\section{Introduction}

It is well known that trace metals originate mainly from metal refining, fossil fuel combustion, automotive exhaust and other human activities [1]. Increasing studies have documented that trace metals mainly exist as particles in the atmosphere and can enter some natural regions with low human disturbance from atmospheric circulation $[1,2]$. The input of trace metals via atmospheric deposition is a large source of contamination for plants, soil and water and a large number of continuous trace metal inputs would have a lasting negative impact on the biogeochemical cycle in an ecosystem [3]. Forest ecosystems can often be called ecologic filters that can efficiently decrease atmospheric pollutants and improve air quality [4,5], however, the efficiency of this filter is often controlled by the precipitation and canopy characteristics.

Trace element is rather loosely used in current literature to designate the elements which occur in small concentrations in natural biologic systems [6]. Trace metals are introduced into terrestrial ecosystems in two forms; specifically, they may be dissolved in rain and snow (i.e., wet deposition), 
or they may enter directly as particulate deposition (i.e., dry deposition) [7]. When precipitation passes through the forest canopy, the precipitation altered by the wash-off of some particles on the canopy and that are deposited in the dry periods or by ion exchange, i.e., uptake or leaching [8]. Finally, some trace elements (e.g., $\mathrm{Pb}$ or $\mathrm{Zn}$ ) $[9,10]$ are taken up by canopy. In addition, $\mathrm{Pb}, \mathrm{Cd}$ and $\mathrm{Cr}$ are classified as non-essential trace elements; however, these elements can be highly toxic and can inhibit growth or cause organismal death [11]. Additionally, $\mathrm{Fe}, \mathrm{Mn}, \mathrm{Cu}, \mathrm{Zn}$ and $\mathrm{Al}$ are essential trace elements that participate in plant physiological and biochemical processes, but excessive amounts of these elements can also be toxic to plants [6].

In forest ecosystems, canopy gaps are created by dead and fallen trees and by intermediate cuttings, which are the primary modes of forest disturbance and regeneration [12,13]. The gap-edge canopy differs substantially from the interior forest zones. First, the gap-edge canopy and the closed canopy represent two different forest canopy conditions, and the coverage of the gap-edge canopy area is less than that of the closed canopy. Therefore, the interception of precipitation will influence the trace metal contents received from the precipitation. Second, the structure of the canopy influences the ability of the canopy to capture suspended particles and suggestion that more trace metals were interception by canopy. Due to the obstruction of the wind profile, which causes local advection and turbulent exchanges, the edge canopy can catch more atmospheric deposition than can the closed canopy [9]. In addition, several studies have focused on the effect of a closed canopy on trace metals from atmospheric deposition [4,14], but these studies have neglected to address the effect of the gap-edge canopy layer on trace metals; thus, the gap-edge canopy should be considered [15]. Therefore, we hypothesis that the fluxes of trace metals in the gap-edge canopy were higher than those in the closed canopy, but the filtration effect on the trace metals in the gap-edge canopy was lower than that in the closed canopy.

Constituting an important freshwater conservation area in the Yangtze River basin, subalpine forests in Southwest China play important roles not only in regulating the regional climate, conservation biodiversity, but also in holding freshwater, and conserving water and soil [16]. Since the 1950s, more than 400,000 hectares of pure dragon spruce plantations have replaced natural coniferous forests on the Tibetan Plateau, and these plantations are harvested by large-scale industrial logging operations. Meanwhile, the forest canopy in plantation has single canopy level rather than natural forest has complex canopy level so the spruce plantation could have not effective in the interception of atmospheric deposition than natural deposition.

The migration and transformation of trace metals occurs through the two external inputs of wet and dry deposition into forest ecosystems, and these processes affect the pollution of trace metals in other parts of the ecosystem. This quantification is necessary given the important biogeochemical role of certain trace metals, either as some essential trace metals such as $\mathrm{Cu}$ and $\mathrm{Zn}$ et al. or as non-essential trace metals (e.g., $\mathrm{Pb}, \mathrm{Cd}$ and $\mathrm{Cr}$ ) in spruce plantation forest ecosystems [9]. Before reaching the soil surface, the chemical composition of precipitation can be modified by the vegetation. The measurement of throughfall is commonly used to describe and quantify the load of atmospheric pollutants in forest ecosystems $[17,18]$, because the content of pollutants in throughfall is changed after rainfall through the forest canopy [9]. Therefore, we measured the trace metals in the throughfall in this area to (1) observe the patterns of annual trace metal concentrations and fluxes from the deposited precipitation and (2) estimate the filter effect of trace metal fluxes between the gap-edge canopy and the closed canopy in a sub-alpine spruce plantation. Knowledge of these processes can enhance the knowledge of the forest canopy trace metal filter effect and evaluate the main processes that control metal behavior after interaction with the forest canopy; Thus, these results can provide the distribution effect of the filtration of trace metals from precipitation in different forest canopy patterns and provide more information for researches on water quality in the upper reaches of the Yangtze River. 


\section{Materials and methods}

\subsection{Site description}

The experiment site is located at the Long-term Research Station of Alpine Forest Ecosystems, Bipenggou Nature Reserve (102-53'-102-57'E, 31-14'-31-19' N; 2458-4619 m a.s.l.), Li County, Sichuan, southwestern China; specifically, the site is situated on the eastern edge of the Tibetan Plateau and in the upper Yangtze River [19]. The mean annual air temperature is $2 \sim 4^{\circ} \mathrm{C}$, and the maximum and minimum temperatures are $23.7^{\circ} \mathrm{C}$ and $-18.1^{\circ} \mathrm{C}$, respectively. The mean annual precipitation ranges from $801 \mathrm{~mm}$ to $850 \mathrm{~mm}$, with most rainfall occurring between May and August; furthermore, snowfall mainly occurs from October to April of the following year. The amount of snowfall was approximately $138.56 \mathrm{~mm}$. The canopy forest vegetation is dominated by Picea asperata with some understory shrubs (e.g., Salix paraplesia and Rhododendron spp.) and grasses (e.g., Berberis diaphana, Sorbus rufopilosa, and Deyeuxia scabrescens). The expanded gap (the canopy gap plus the area that expands to the bases of the surrounding canopy trees) covers $23 \%$ of the experimental site [20].

\subsection{Experimental design}

Three plots with similar topographical and environmental features were selected in a typical spruce forest gap (the area: $100 \mathrm{~m}^{2}$ ) along a gradient from the gap-edge to the closed canopy (the closed canopy area was $20 \mathrm{~m} \times 20 \mathrm{~m}$ ) at $3000 \mathrm{~m}$ a.s.1. The mean tree age was approximately 60 a. The average diameter at breast height $(\mathrm{DBH})$ and the average tree height was $19.53 \pm 1.99 \mathrm{~cm}$ and $7.63 \pm$ $0.45 \mathrm{~m}$, respectively, in the experimental plots. In addition, we selected an open area $(20 \mathrm{~m} \times 20 \mathrm{~m})$ that was approximately $50 \mathrm{~m}$ from the edge of the spruce plantation forest, and this area was selected as the non-forest site to collect precipitation.

\subsection{Precipitation observation and water sampling}

Precipitation: the rainfall was sampled in the non-forest site using 5 homemade continuous rain gauges (surface collection area of $0.64 \mathrm{~m}^{2}$ ).

Snowfall: 5 cone-shaped collectors (top diameter of $100 \mathrm{~cm}$, bottle diameter about of $20 \mathrm{~cm}$ ) made of PVC and gridding cloth were used to observe and sample snowfall in the open site and were established $1 \mathrm{~m}$ above the floor, and each collector was drained into a polyethylene (PE) bucket, the snowfall was straight drop into the polyethylene bucket, that won't be exposed for a long time outside and decrease the snowfall evaporation.

Throughfall in the rainy season: the throughfall was recorded using 5 PVC rectangular grooves (surface collection area of $400 \mathrm{~cm} \times 16 \mathrm{~cm}$ ) that were arranged beneath the closed canopy and the gap-edge canopy in each plot; additionally, 5 grooves were established $1 \mathrm{~m}$ above the floor to avoid ground splash effects. Furthermore, the gutters were also established at a $5^{\circ}$ horizontal angle to promote drainage, and the lower end of each gutter was equipped with a plastic bucket.

Throughfall in the snowy season: 5 cone-shaped collectors that were similar to the snowfall collectors were distributed beneath the closed canopy and the gap-edge canopy in each plot, and each collector was drained into a PE bucket.

\subsection{Chemical analyses}

Water samples were collected immediately after each rainfall event during the rainy season from August 2015 to July 2016. And we collected the snowfall samples once each month from November 2015 to April 2016 because the snowfall was heavy, and the field conditions were difficult and placed them in clean polyethylene bottles. The samples were quickly transported to the laboratory, where they were filtered using qualitative filter paper with diameter of $12.5 \mathrm{~cm}$. The filtered samples were adjusted to a $\mathrm{pH}$ of 1 2 with high-purity grade (GR) nitric acid. The concentrations of tracer metals (i.e., $\mathrm{Fe}, \mathrm{Mn}, \mathrm{Cu}, \mathrm{Zn}, \mathrm{Al}, \mathrm{Pb}, \mathrm{Cd}$ and $\mathrm{Cr}$ ) were determined using inductively coupled plasma optical emission spectrometry (Agilent 5000). 
2 of 13

\subsection{Calculations}

The fluxes of precipitation and throughfall was calculated by formula (1) as follow: [21]

$$
\operatorname{Flux}_{j}=\frac{V W M_{j} \times V_{j}}{100}
$$

where Flux $\mathrm{j}$ is the deposition flux of the solute $\mathrm{j}$ in different forms of water, $\mathrm{VWM}_{\mathrm{j}}$ is the weighted concentration $\left(\mathrm{mg} \mathrm{L}^{-1}\right)$ of the solute $\mathrm{j}$ in different forms of water, $\mathrm{V}_{\mathrm{j}}$ is the water is the water of different forms (mm), and 100 is the unit conversion factor.

The net throughfall flux (NTF) and (NTR) was calculated by Equation (2) and Equation (3) [22]:

$$
\begin{gathered}
\mathrm{NTF}=\mathrm{TF}-\mathrm{BP}(2) \\
\mathrm{NTR}=\mathrm{NTF} / \mathrm{BP}(3)
\end{gathered}
$$

BP and TF represent the bulk precipitation flux $\left(\mathrm{kg} \mathrm{ha}^{-1}\right)$ and the throughfall flux $\left(\mathrm{kg} \mathrm{ha}^{-1}\right)$, respectively. (The negative and positive NTF (NTR) values represent the filtered and leached amounts, respectively).

\subsection{Statistical analysis}

All statistical analyses were carried out using IBM SPSS Statistics 20.0. The Univariate analysis was used to compare the concentrations, fluxes and net throughfall fluxes of trace metals at different canopy and season. The statistical tests were considered significant at the $P<0.05$ level.

\section{Results}

\subsection{The annual variation of trace metal concentrations in precipitation and throughfall}

After precipitation passes through the canopy, the concentrations of trace metals increase and decrease at different levels in the closed canopy and gap-edge canopy. In the rainy season, the throughfall concentrations of the essential trace metals of $\mathrm{Fe}, \mathrm{Mn}$ and $\mathrm{Cu}$ in the closed canopy and the gap-edge canopy were higher than those in the precipitation (Figure 1); furthermore, and the concentration of Mn was 2.63-fold and 1.68-fold higher in the closed canopy and gap-edge canopy than in the precipitation. In addition, the concentrations of $\mathrm{Fe}, \mathrm{Mn}$ and $\mathrm{Cu}$ in the closed canopy were higher than those in the gap-edge canopy. Only $\mathrm{Cr}$ increased in the gap-edge canopy among the non-essential trace metals (Figure 2). In the snowy season, the throughfall concentrations of all trace metals in the closed canopy and gap-edge canopy were lower than those in the precipitation, and the concentrations of trace metals in the closed canopy were higher than those in the gap-edge canopy (except for $\mathrm{Al}$ and $\mathrm{Pb}$ ). Furthermore, there were no significant differences in the trace metal concentrations between the gap-edge canopy and the closed canopy and the season has significant differences in trace metal concentration in table $2(P<0.05)$. 


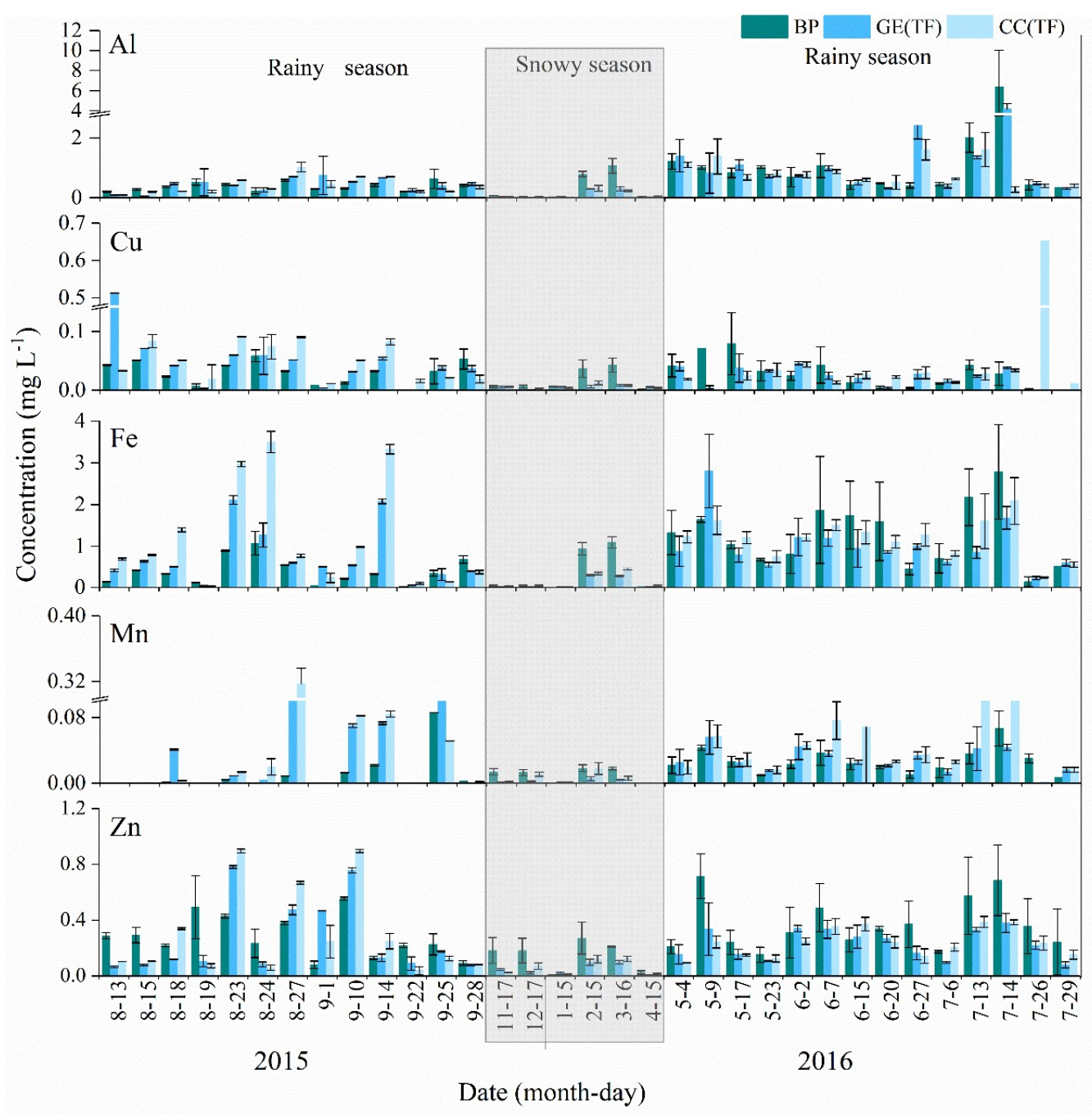

Figure 1. The concentrations of essential-trace metals in bulk precipitation and throughfall: BP: bulk precipitation. GE: gap-edge canopy. CC: closed canopy. The bar graphs with error bars are the means with $95 \%$ confidence intervals. 


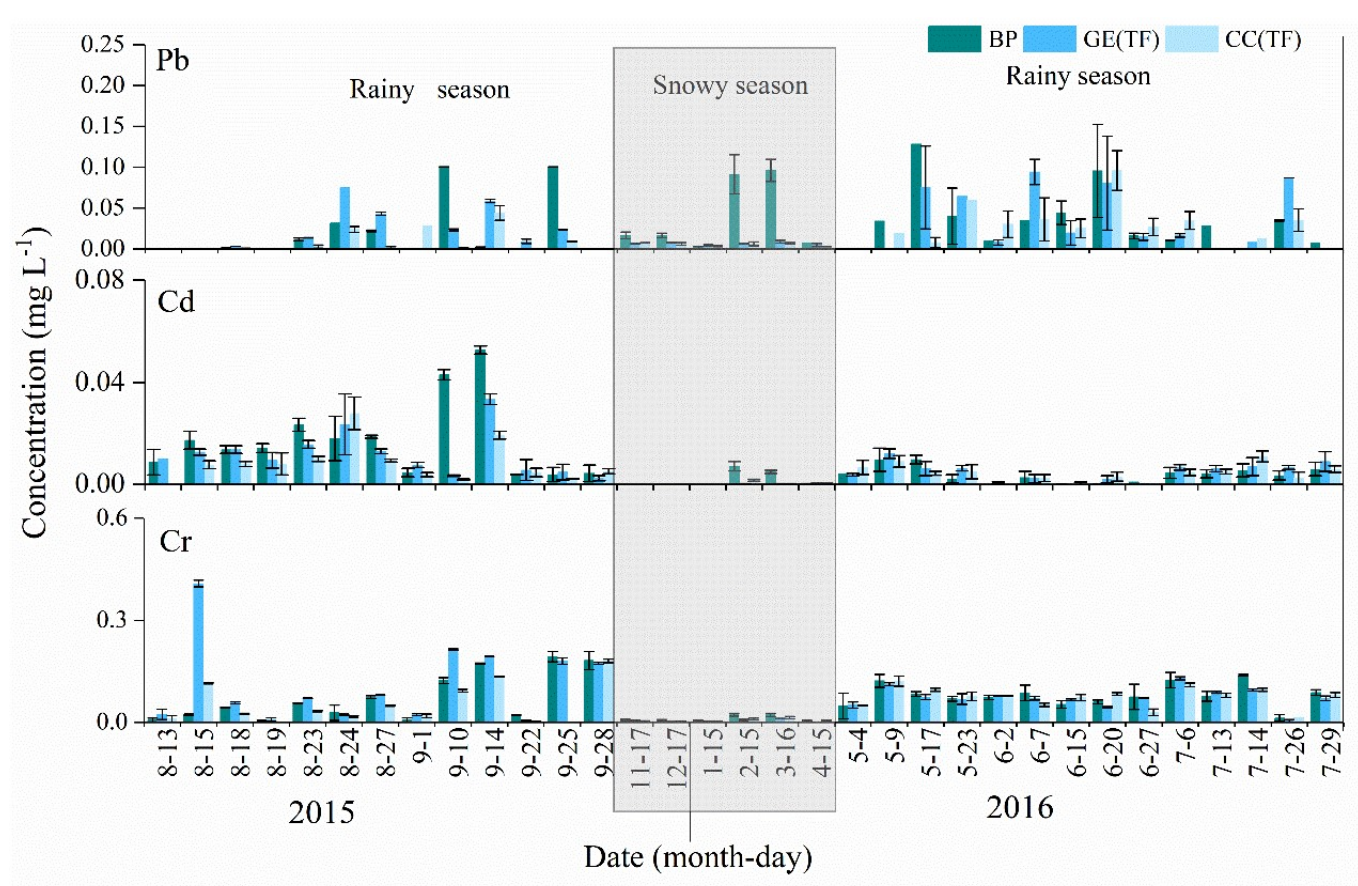

Figure 2. The concentrations of non-essential trace metals in bulk precipitation and throughfall: BP: bulk precipitation. GE: gap-edge canopy. CC: closed canopy. The bar graphs with error bars are the means with $95 \%$ confidence intervals.

\subsection{The annual variation of trace metal fluxes in precipitation and throughfall}

The annual fluxes of $\mathrm{Al}, \mathrm{Zn}, \mathrm{Fe}, \mathrm{Mn}, \mathrm{Cu}, \mathrm{Cd}, \mathrm{Cr}$ and $\mathrm{Pb}$ were $7.29 \mathrm{~kg} \cdot \mathrm{ha}^{-1}, 2.30 \mathrm{~kg} \cdot \mathrm{ha}^{-1}, 7.02$ $\mathrm{kg} \cdot \mathrm{ha}^{-1}, 0.16 \mathrm{~kg} \cdot \mathrm{ha}^{-1}, 0.19 \mathrm{~kg} \cdot \mathrm{ha}^{-1}, 0.06 \mathrm{~kg} \cdot \mathrm{ha}^{-1}, 0.56 \mathrm{~kg} \cdot \mathrm{ha}^{-1}$ and $0.24 \mathrm{~kg} \cdot \mathrm{ha}^{-1}$, respectively. And shown the rainy season higher than snowy season (figure 3,4). The input of all trace metals from the precipitation, gap-edge canopy and closed canopy was $1.15 \mathrm{~kg} \cdot \mathrm{ha}^{-1}, 0.29 \mathrm{~kg} \cdot \mathrm{ha}^{-1}$ and $0.30 \mathrm{~kg} \cdot \mathrm{ha}^{-1}$, respectively, in the snowy season and $16.68 \mathrm{~kg} \cdot \mathrm{ha}^{-2}, 13.02 \mathrm{~kg} \cdot \mathrm{ha}^{-2}$ and $15.96 \mathrm{~kg} \cdot \mathrm{ha}^{-2}$, respectively, in the rainy season. Additionally, the maximum values of all trace metal fluxes in the precipitation, closed canopy and gap-edge canopy were observed for $\mathrm{Fe}$ and $\mathrm{Al}$ in both seasons. In the snowy season, the throughfall fluxes of all trace metals in the closed canopy and gap-edge canopy were lower than those in the precipitation. Furthermore, there were no significant differences in trace metal fluxes between the gap-edge canopy and the closed canopy, and the season has significant differences in trace metal fluxes in table $2(P<0.05)$. 


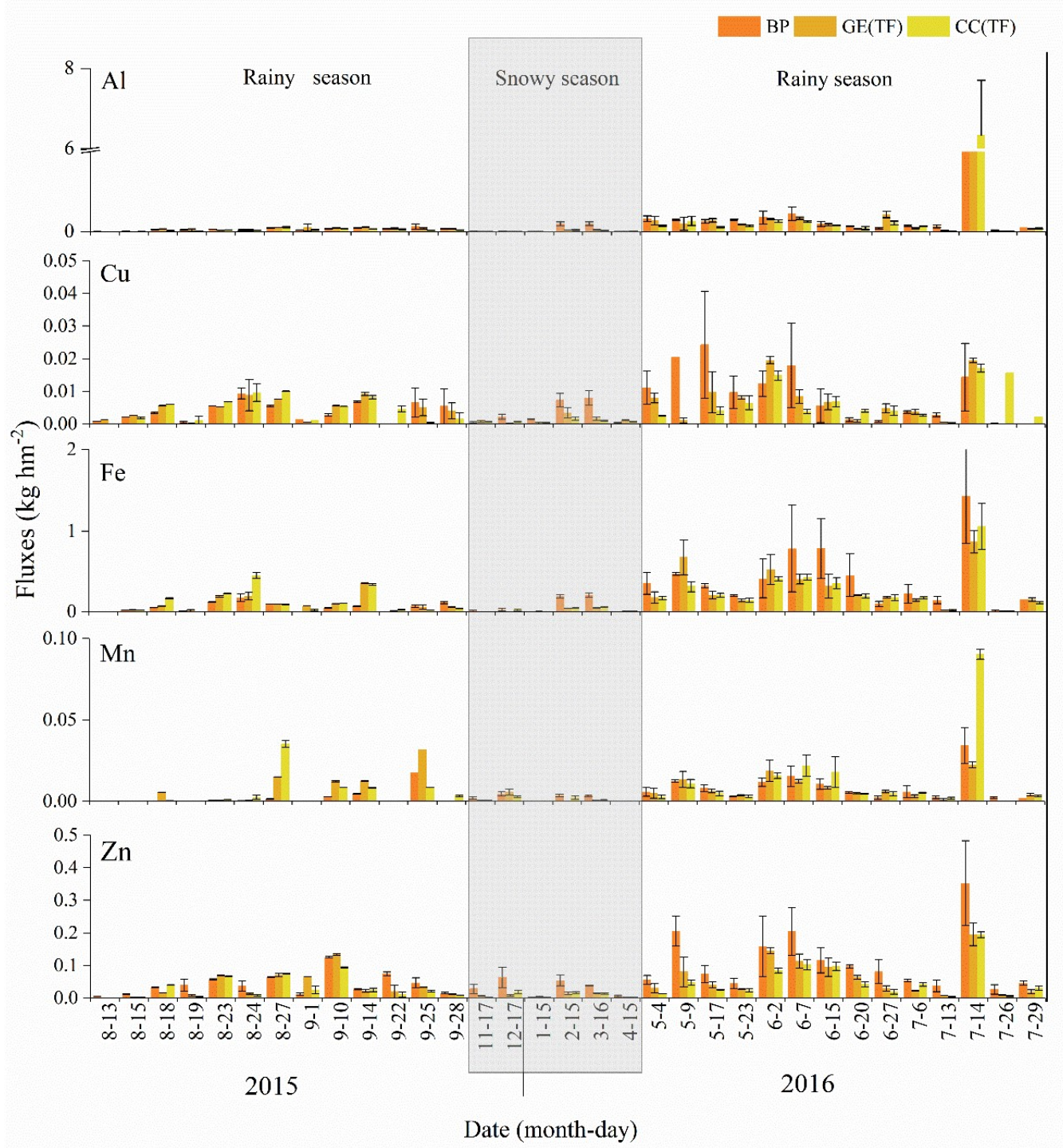

Figure 3. The fluxes of essential trace metals in bulk precipitation and throughfall: BP: bulk precipitation. GE: gap-edge canopy. CC: closed canopy. The bar graphs with error bars are the means with $95 \%$ confidence intervals. 


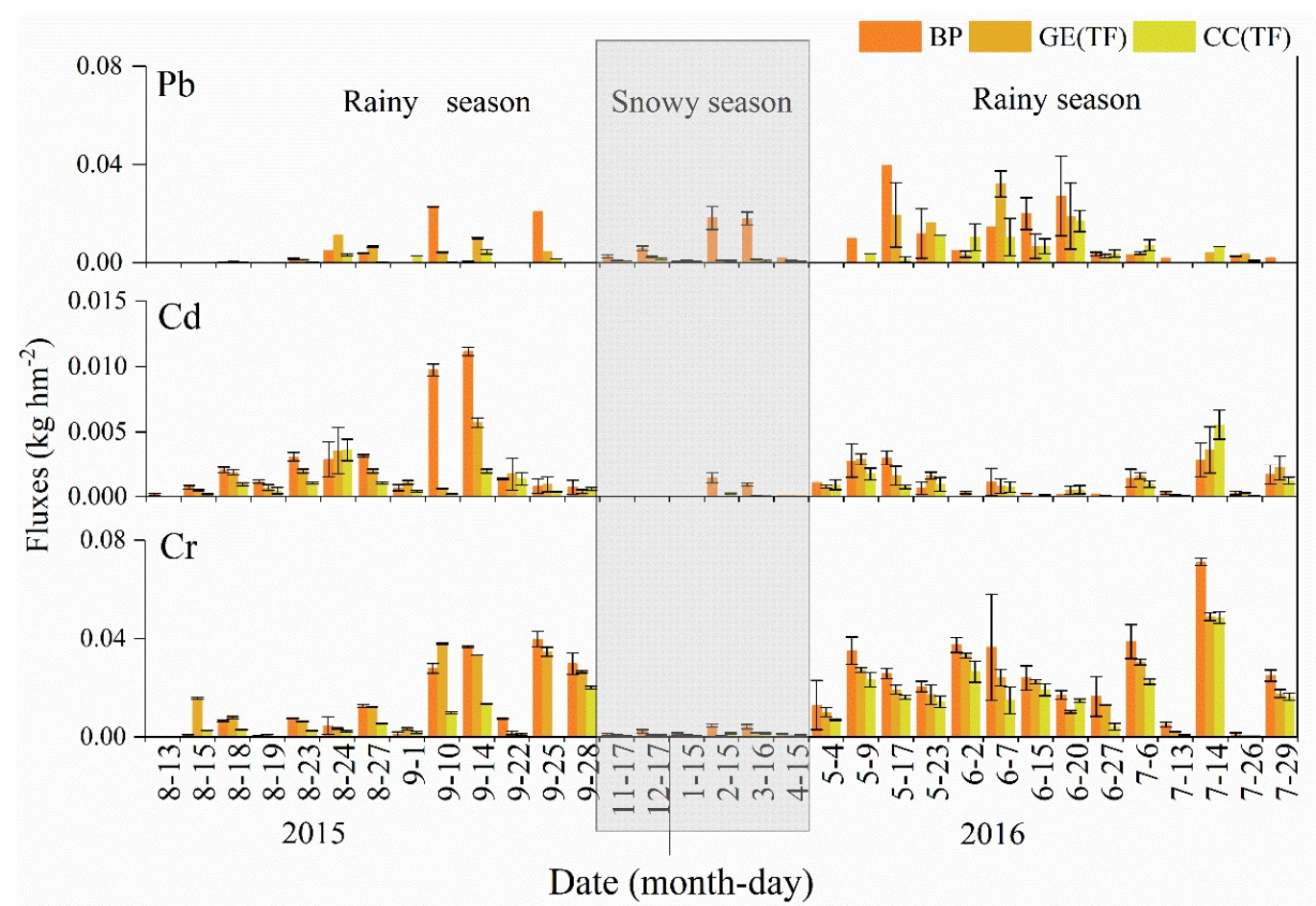

Figure 4. The fluxes of essential non-essential trace metals in bulk precipitation and throughfall: BP: bulk precipitation. GE: gap-edge canopy. CC: closed canopy. The bar graphs with error bars are the means with $95 \%$ confidence intervals.

\subsection{The variation of net throughfall fluxes of trace metals in closed canopy and gap-edge canopy}

The net throughfall fluxes and net throughfall ratio of $\mathrm{Al}, \mathrm{Zn}, \mathrm{Fe}, \mathrm{Mn}, \mathrm{Cu}, \mathrm{Cd}, \mathrm{Cr}$ and $\mathrm{Pb}$ are shown in table 1 . The annual NTFs of these trace metals in gap edge canopy were $-1.41 \mathrm{~kg} \cdot \mathrm{ha}^{-1},-0.76$ $\mathrm{kg} \cdot \mathrm{ha}^{-1},-1.35 \mathrm{~kg} \cdot \mathrm{ha}^{-1}, 0.04 \mathrm{~kg} \cdot \mathrm{ha}^{-1},-0.02 \mathrm{~kg} \cdot \mathrm{ha}^{-1},-0.02 \mathrm{~kg} \cdot \mathrm{ha}^{-1},-0.08 \mathrm{~kg} \cdot \mathrm{ha}^{-1}$ and $-0.04 \mathrm{~kg} \cdot \mathrm{ha}^{-1}$ during

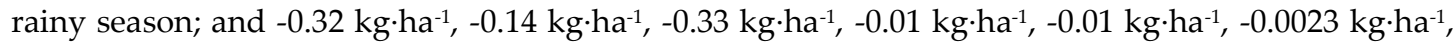
$-0.01 \mathrm{~kg} \cdot \mathrm{ha}^{-1}$ and $-0.04 \mathrm{~kg} \cdot \mathrm{ha}^{-1}$ during snowy season. The NTFs of these trace metals in closed canopy were $1.93 \mathrm{~kg} \cdot \mathrm{ha}^{-1},-0.99 \mathrm{~kg} \cdot \mathrm{ha}^{-1},-1.35 \mathrm{~kg} \cdot \mathrm{ha}^{-1}, 0.11 \mathrm{~kg} \cdot \mathrm{ha}^{-1},-0.03 \mathrm{~kg} \cdot \mathrm{ha}^{-1},-0.03 \mathrm{~kg} \cdot \mathrm{ha}^{-1},-0.25 \mathrm{~kg} \cdot \mathrm{ha}^{-1}$ and -0.10 $\mathrm{kg} \cdot \mathrm{ha}^{-1}$ during rainy season; and $-0.26 \mathrm{~kg} \cdot \mathrm{ha}^{-1},-0.14 \mathrm{~kg} \cdot \mathrm{ha}^{-1},-0.30 \mathrm{~kg} \cdot \mathrm{ha}^{-1},-0.01 \mathrm{~kg} \cdot \mathrm{ha}^{-1},-0.01 \mathrm{~kg} \cdot \mathrm{ha}^{-1}$, $-0.0022 \mathrm{~kg} \cdot \mathrm{ha}^{-1},-0.01 \mathrm{~kg} \cdot \mathrm{ha}^{-1}$ and $-0.04 \mathrm{~kg} \cdot \mathrm{ha}^{-1}$ during snowy season. and the The NTR of Mn was $33 \%$ and $89 \%$ in rainy season in different canopy that show the higher leaching among the trace metals. 
Table 1 The net throughfall fluxes (NTF)and net throughfall ratio (NTR) and standard deviation (in brackets) of trace metals in closed canopy and gap edge canopy during rainy and snowy season.

\begin{tabular}{|c|c|c|c|c|c|c|c|c|c|c|c|}
\hline Canopy & Season & Througl & all $(\mathrm{mm}) \quad$ Items & Al & $\mathbf{Z n}$ & $\mathrm{Fe}$ & Mn & $\mathrm{Cu}$ & Cd & $\mathrm{Cr}$ & $\mathbf{P b}$ \\
\hline \multirow{6}{*}{ Gap edge canopy } & \multirow{2}{*}{ Annual } & \multirow{2}{*}{645.47} & $\operatorname{NTF}\left(\mathrm{kg} \cdot \mathrm{ha}^{-1}\right)$ & 1.73 & 0.9 & 1.68 & -0.032 & 0.04 & 0.018 & 0.093 & 0.087 \\
\hline & & & NTR (\%) & 23.73 & 39.2 & 23.93 & -19.75 & 20.62 & 32.85 & 26.7 & 35.95 \\
\hline & \multirow{2}{*}{ Rainy season } & \multirow{2}{*}{530.33} & $\operatorname{NTF}\left(\mathrm{kg} \cdot \mathrm{ha}^{-1}\right)$ & $-1.41(1.74)$ & $-0.76(0.41)$ & $-1.35(1.35)$ & $0.04(0.01)$ & $-0.02(0.05)$ & $-0.02(0.00)$ & $-0.08(0.05)$ & $-0.04(0.02)$ \\
\hline & & & NTR (\%) & $-36(44)$ & $-52(28)$ & $-32(32)$ & $33(8)$ & $-25(50)$ & $-39(1)$ & $-18(11)$ & $-27(13)$ \\
\hline & \multirow{2}{*}{ Snowy season } & \multirow{2}{*}{115.14} & $\operatorname{NTF}\left(\mathrm{kg} \cdot \mathrm{ha}^{-1}\right)$ & $-0.32(0.1)$ & $-0.14(0.05)$ & $-0.33(0.04)$ & $-0.01(0.00)$ & $-0.01(0.00)$ & $-0.0023(0.00)$ & $-0.01(0.00)$ & $-0.04(0.01)$ \\
\hline & & & NTR (\%) & $-100(32)$ & $101(38)$ & $'-82(4)$ & $-49(19)$ & $-61(16)$ & $-95(12)$ & $-79(22)$ & 101(17) \\
\hline \multirow{6}{*}{ Closed canopy } & \multirow{2}{*}{ Annual } & \multirow{2}{*}{516.17} & $\operatorname{NTF}\left(\mathrm{kg} \cdot \mathrm{ha}^{-1}\right)$ & -1.6 & 1.13 & 1.65 & -0.1 & 0.047 & 0.03 & 0.26 & 0.15 \\
\hline & & & NTR (\%) & -21.91 & 49.23 & 23.47 & 61.11 & 24.22 & 53.5 & 46.81 & 60.33 \\
\hline & \multirow{2}{*}{ Rainy season } & \multirow{2}{*}{422.26} & NTF $\left(\mathrm{kg} \cdot \mathrm{ha}^{1}{ }^{1}\right)$ & $1.93(0.83)$ & $-0.99(0.50)$ & $-1.35(1.57)$ & $0.11(0.02)$ & $-0.03(0.06)$ & $-0.03(0.00)$ & $-0.25(0.05)$ & $-0.10(0.01)$ \\
\hline & & & NTR (\%) & $49(21)$ & $-68(34)$ & $-32(37)$ & $89(16)$ & $-31(56)$ & $-66(11)$ & $-53(11)$ & $-64(5)$ \\
\hline & \multirow{2}{*}{ Snowy season } & \multirow{2}{*}{93.91} & $\operatorname{NTF}\left(\mathrm{kg} \cdot \mathrm{ha}^{-1}\right)$ & $--0.26(0.22)$ & $-0.14(0.05)$ & $-0.30(0.04)$ & $-0.01(0.00)$ & $-0.01(0.00)$ & $-0.0022(0.00)$ & $-0.01(0.00)$ & $-0.04(0.01)$ \\
\hline & & & NTR (\%) & $-82(68)$ & $-97(37)$ & $-75(11)$ & $-57(12)$ & $103(32)$ & $-91(8)$ & $-80(18)$ & $107(17)$ \\
\hline
\end{tabular}

Table 2 The result ( $F$ value) of Univariate analysis on the effect of canopy and season on concentration and fluxes of trace metals in throughfall

\begin{tabular}{|c|c|c|c|c|c|c|c|c|c|}
\hline & Item & $\mathrm{Al}$ & $\mathrm{Zn}$ & $\mathrm{Fe}$ & $\mathrm{Mn}$ & $\mathrm{Cu}$ & $\mathrm{Pb}$ & $\mathrm{Cd}$ & $\mathrm{Cr}$ \\
\hline \multirow{2}{*}{ Concentration } & Canopy & 0.22 & 0.22 & 1.64 & 1.25 & 0.13 & 0.88 & 0.72 & 1.403 \\
\hline & Season & $7.7 * *$ & $31.83 * *$ & $44.60 * *$ & $12.242 * *$ & $6.89 * *$ & 11.18 & $37.28 * *$ & $39.939 * *$ \\
\hline \multirow{2}{*}{ Fluxes } & Canopy & 0.78 & 0.38 & 0.1 & 0.24 & 0.49 & 1.316 & 0.83 & 2.28 \\
\hline & Season & $27.96 * *$ & $21.93 * *$ & $52.23 * *$ & $8.89 * *$ & $23.58 * *$ & $9.315 * *$ & $24.77 * *$ & $39.59 * *$ \\
\hline \multirow{2}{*}{ NTF } & Canopy & 0.60 & 1.02 & 0.005 & $5.06^{*}$ & 0.57 & $5.57 *$ & 1.32 & $10.59 * *$ \\
\hline & Season & 0.54 & 0.32 & 0.004 & 0.48 & 0.24 & 0.57 & 0.26 & $4.74 *$ \\
\hline
\end{tabular}

${ }^{*}: P<0.05 ;{ }^{* *}: P<0.01$. 


\section{Discussion}

Before reaching the soil surface, the chemical composition of precipitation can be modified by vegetation [22], due to the interaction between precipitation and the canopy can exchange with ions and the concentrations of the elements were changed[23]. The concentration changes in snowy season and rainy season have obvious seasonal characteristics (figure 1,2), because the effect of freezing and thawing, the cell membrane of plant leaves is damaged, and the change of water content in tissues affects the exchange ability between cells and ions[24,25,26], and the variation of season has a significant effect on trace metals (table 2). The enrichment extent is relevant to the solute characteristics [27], the higher concentrations of trace metals in precipitation are from terrigenous particles, such as $\mathrm{Al}$ and $\mathrm{Fe}$, and the Sonja which supported our findings[28]. thus, higher concentrations of $\mathrm{Al}$ and $\mathrm{Fe}$ among the trace metals result in higher fluxes in precipitation. Compared with non-forest, the trace metal concentration of $\mathrm{Al}$ was lower in the gap-edge canopy and the closed canopy during both seasons, but the concentration of Fe was higher in the gap-edge canopy and closed canopy in the rainy season. And the concentrations of $\mathrm{Al}$ and Fe account for $42.5 \%$ and $40.8 \%$ of the non-forest input in the rainy season, and $37.6 \%$ and $38.0 \%$, in the snowy season.

The brief interaction between vegetation and precipitation creates high spatial variability of metal deposition from throughfall, which is very important for elemental cycling in forest ecosystems $[29,30]$. The concentration of trace metals in precipitation were higher than those in throughfall due to snowfall has higher evaporation and the open field effect higher solar radiation in winter. However, the canopy has no significant effect on fluxes of trace metals. Consistent with our hypothesis, the results indicated that the annual fluxes of most trace metals (e.g., $\mathrm{Zn}, \mathrm{Cd}, \mathrm{Cr}, \mathrm{Cu}$ and $\mathrm{Pb}$ ) in the gap-edge canopy were higher than those in the closed canopy. First, due to the proximity of the edge affects the wind speed and enhances the air turbulence, increasing the dry deposition velocities via inflow and advection processes and the coniferous foliage surface has a particular capacity to trap the dry deposition [31,32]. Then, the precipitation can wash off more of these metal particles from the gap-edge canopy, and the throughfall deposition of $\mathrm{Zn}, \mathrm{Cd}, \mathrm{Cr}, \mathrm{Cu}$ and $\mathrm{Pb}$ at the gap-edge canopy is significantly enhanced relative to that in the closed canopy in our study. The throughfall deposition of $\mathrm{Zn}, \mathrm{Cd}, \mathrm{Cr}, \mathrm{Cu}$ and $\mathrm{Pb}$ in gap-edge canopy was 1.20-, 0.14-, 1.57-, 1.05- and 2.68-fold higher than those in closed canopy. The gaps have higher air temperatures and solar radiation than do the closed forests, and evaporation on the leaves is another critical contributing factor that is responsible for the increase in metal concentrations in throughfall[33 34] So would increase concentration of $\mathrm{Cd}, \mathrm{Cr}$ and $\mathrm{Pb}$ in the gap-edge canopy were 1.31-, 1.43- and 1.43-fold higher than those in the closed canopy, respectively.

The net throughfall input is the combined result of leaching and uptake in the canopy[10] and also relative with the vegetation the element of $\mathrm{Fe}$ and $\mathrm{Mn}$ in pine-oak forest and the oak forest was leaching, but in our study, the filter was often the result of trace metals leaching (expect for $\mathrm{Mn}$ ), which indicates that the tracer metals were filtered (e.g., adsorbed or retained) by the canopy, and the $\mathrm{Mn}$ in closed canopy was 1.11- and 2.38 fold higher than the pine-oak forest and oak forest [35]. In addition, $\mathrm{Zn}, \mathrm{Fe}, \mathrm{Cu}, \mathrm{Cd}, \mathrm{Cr}$ and $\mathrm{Pb}$ were filtered by the gap-edge canopy and the closed canopy, and the net filtering ratio of these metals in the closed canopy was higher than that in the gap-edge canopy, and the net filtering ratio of $\mathrm{Zn}$ was $30.25 \%$ and $25.00 \%$ in two evergreen oak stands in Spain was lower than the $\mathrm{Zn}$ in our study[9]. In addition, the net filtering ratio was $36 \%$ of $\mathrm{Al}$ was filtered in the gap-edge canopy, and $49 \%$ was leached in the closed canopy during the rainy season. However, the net filtering ratio of all trace metals was over than $50 \%$ in the snowy season. There are two mechanisms in which foliar structures filter metals: (1) through the absorption and internalization of the cuticle and (2) the penetration of metals through the stomatal pore [36]. The stomatal openings and cuticle expansion allow a high level of metal penetration from the atmosphere [37]. The canopy retention of $\mathrm{Zn}$ and $\mathrm{Cd}$ has been reported in other studies [38,39], and some studies also found canopy uptake of $\mathrm{Zn}, \mathrm{Cd}, \mathrm{Cu}$ and $\mathrm{Pb}$ [40]. Non-essential trace metals, such as $\mathrm{Pb}$ [41,42], $\mathrm{Cd}[43]$ and $\mathrm{Cr}[44]$, can also enter plant leaves via foliar transfer, and these metals can 
penetrate cuticles and finally accumulate in leaf tissues, and the canopy filtered the $\mathrm{Pb}$ and $\mathrm{Cd}$ was over than $80 \%$ in mid-subtropical forest which was higher than gap edge canopy and closed canopy[45]. Among the essential trace metals, Mn presented the highest level of leaching in both canopies in the rainy season, and this result is widely attributed in the literature to canopy leaching $[10,38,46,47,48,49,50]$. Additionally, the enrichment factor of Mn demonstrated that there was a higher enrichment in throughfall, and this phenomenon was also found in Gandois' research [51], who attributed the results to internal cycling [38].

\section{Conclusion}

The forest canopy can be regarded as a self-regulating system that filters certain trace metals from deposited precipitation. The annual fluxes of trace metal in precipitation was $17.83 \mathrm{~kg} \cdot \mathrm{ha}^{-1}$, and the rainy season account for $93.55 \%$, and the trace metals in precipitation were filtered by the closed canopy and gap-edge canopy by $4.3 \%$ and $21.94 \%$, respectively. Meanwhile, the snowy season, account for $6.45 \%$ of precipitation, and the trace metals in precipitation were filtered by the closed canopy and gap-edge canopy by $73.95 \%$ and $75.11 \%$, respectively. For essential trace metals, the closed canopy leached $28.06 \%$ of $\mathrm{Al}$ and $71.10 \%$ of $\mathrm{Mn}$, while the closed canopy filtered $47.14 \%$, $20.43 \%, 16.66 \%, 52.55 \%, 46.35 \%$ and $53.32 \%$ of the $\mathrm{Zn}, \mathrm{Fe}, \mathrm{Cu} . \mathrm{Pb}, \mathrm{Cd}$ and $\mathrm{Cr}$, respectively. The gap-edge canopy leached $25.99 \%$ of $\mathrm{Mn}$, and it filtered $20.58 \%, 35.93 \%,-20.50 \%, 25.99 \%, 31.10 \%$, $15.30 \%$ and $22.44 \%$ of $\mathrm{Al}, \mathrm{Zn}, \mathrm{Fe}, \mathrm{Zn}, \mathrm{Pb}, \mathrm{Cd}$ and $\mathrm{Cr}$, respectively. However, all trace metals demonstrated a high net filtering ratio in the gap-edge canopy and closed canopy in the snowy season. These results which provided us a clearer idea to the filtration effect of subalpine forest on trace metals from precipitation deposition and help protect water quality in the upper reaches of the Yangtze River.

Acknowledgments: This work was supported by the National Key Technologies R \& D Program of China (2017YFC0505003), the Key Technologies R \& D Program of Sichuan (18ZDYF0307), Fok Ying-Tong Education Foundation for Young Teachers (161101) and the Sichuan Provincial Science and Technology Project for Youth Innovation Team (2017TD0022).

\section{References}

1. [1] Hou, H., T. Takamatsu, M. K. Koshikawa, and M. Hosomi. Trace metals in bulk precipitation and throughfall in a suburban area of Japan. Atmospheric Environment 2005,39, 3583-3595.

2. [2] Rauch, J. N. and J. M. Pacyna. Earth's global Ag, Al, Cr, $\mathrm{Cu}, \mathrm{Fe}, \mathrm{Ni}, \mathrm{Pb}$, and $\mathrm{Zn}$ cycles. Global Biogeochemical Cycles 2009,23, n/a-n/a.

3. [3] Siudek, P. and M. Frankowski. Atmospheric deposition of trace elements at urban and forest sites in central Poland-Insight into seasonal variability and sources. Atmospheric Research 2017,198, 123-131.

4. [4] Mayer, R. and B. Ulrich. Input of atmospheric sulfur by dry and wet deposition to two central European forest ecosystems. Atmospheric Environment 1978,12, 375-377.

5. [5] C. S .C Wong. X. D. Li, G. Zhang, S. H. Qiand. Z. Peng. Atmospheric deposition of heavy metals in the Pear Delta, China. Atmospheric Environment 2003,3, 767-776.

6. [6] Nagajyoti, P. C. and K. D. Lee and T. V. M. Sreekanth. Heavy metals, occurrence and toxicity for plants: a review. Environmental Chemistry Letters 2010, 8:199-216.

7. [7] Lee, C. S. L. Heavy metal concentrations and Pb isotopic composition in urban and suburban aerosols of Hong Kong and Guangzhou, South China-Evidence of the long-range transport of air contaminants. Acta Geochimica 2006,25, 123-124.

8. [8] Draaijers GPJ, Erisman JW, VanLeeuwen NFM, Romer FG, TE Winkel BH, Veltkamp AC, Vermeulen AT, Wyers GP. The impact of canopy exchange on differences observed between atmospheric deposition and throughfall fluxes. Atmospheric Environment 1997,31, 387-397.

9. [9] Avila, A. and A. Rodrigo. Trace metal fluxes in bulk deposition, throughfall and stemflow at two evergreen oak stands in NE Spain subject to different exposure to the industrial environment. Atmospheric Environmental 2004,38, 171-180. 
10. [10] Zhang, S. and C. Liang. Effect of a native forest canopy on rainfall chemistry in China's Qinling Mountains. Environmental Earth Sciences 2012,67, 1503-1513.

11. [11] Stiller, M. and L. Sigg. Heavy metals in the Dead Sea and their coprecipitation with halite. Hydrobiologia 1990, 197:23-33.

12. [12] Staelens, J., D. Houle, D. S. An, J. Neirynck, and K. Verheyen. Calculating Dry Deposition and Canopy Exchange with the Canopy Budget Model: Review of Assumptions and Application to Two Deciduous Forests. Water Air \& Soil Pollution 2008,191, 149-169.

13. [13] Sun, X. Y. and G. X. Wang. The Hydro-chemical Characteristics Study of Forest Ecosystem Precipitation Distribution in Gongga Mountain. Research of Soil \& Water Conservation 2009,16, 120-124.

14. [14] Guo, J., S. Kang, J. Huang, Q. Zhang, L. Tripathee, and M. Sillanpää. Seasonal variations of trace elements in precipitation at the largest city in Tibet, Lhasa. Atmospheric Research 2015,153, 87-97.

15. [15] Wuyts, K., A. D. Schrijver, K. Verheyen, and M. Schaub. The importance of forest type when incorporating forest edge deposition in the evaluation of critical load exceedance. I forest Biogeosciences $\mathcal{E}$ Forestry 2009,2, 385-392.

16. [16] Yang, W.Q., Wang, K.Y., Kellomki, S. \& Gong, H. D. Litter dynamics of Three subalpine forests in Western Sichuan. Pedosphere 2005,15, 653.

17. [17] Hultberg, H. and P. Grennfelt. Sulphur and seasalt deposition as reflected by throughfall and runoff chemistry in forested catchments. Environmental Pollution 1992,75, 215-222.

18. [18] Derome, J. and T. Nieminen. Metal and macronutrient fluxes in heavy-metal polluted Scots pine ecosystems in SW Finland. Environmental Pollution 1998,103, 219-228.

19. [19] Yang, W. Q., K. Y. Wang, S. Kellomki, and Z. Jian. Annual and Monthly Variations in Litter Macronutrients of Three Subalpine Forests in Western China. Pedosphere 2006,16, 788-798.

20. [20] Wu, Q. G., Wu, F.Z., Yang, W.Q., Tan, B., Yang, Y. L., Ni, X. Y., He, J. Characteristics of Gaps and Disturbance Regimes of the Alpine Fir Forest in Western Sichuan. Chinese Journal of Applied $\mathcal{E}$ Environmental Biology 2013,19, 922.

21. [21] Lu, J., S. Zhang, J. Fang, H. Yan, and J. Li. Nutrient Fluxes in Rainfall, Throughfall, and Stemflow in Pinus densata Natural Forest of Tibetan Plateau. Clean - Soil Air Water 2017,45,1600008.

22. [22] Lovett, G. M. and S. E. Lindberg. Dry Deposition and Canopy Exchange in a Mixed Oak Forest as Determined by Analysis of Throughfall. Journal of Applied Ecology 1984,21, 1013-1027.

23. [23] Özsoy, T. and S. Örnektekin. Trace elements in urban and suburban rainfall, Mersin, Northeastern Mediterranean. Atmospheric Research 2009,94, 203-219.

24. [24] Schmidt, R. A. and D. R. Gluns. Snowfall Interception on Branches of Three Conifer Species. C anadian Journal Of Forest Research 1991,21:1262-1269.

25. [25] Bao, W. and W. Bao and H. E. Binghui. Redistribution effects of tree canopy of the artificial Pinus tabulaeformis forest on precipitation in the upper stream of Minjiang River. Journal of Beijing Forestry University 2004,26:10-16.

26. [26] Xiao Q Y, Yin CY, Pu XZ, Qiao MF and Liu Q. Ecophysiological characteristics of leaves and fine roots in dominant tree species in a subalpine coniferous forest of western Sichuan during seasonal frozen soil period. Chinese Journal of Plant Ecology 2014,38:343-345.

27. [27] Lu, J., S. Zhang, J. Fang, H. Yan, and J. Li. Nutrient Fluxes in Rainfall, Throughfall, and Stemflow in Pinus densata Natural Forest of Tibetan Plateau. Clean - Soil Air Water 2017,45,1600008.

28. [28] Sonja, G., N. Christopher, K. Alexv, N. Sergiocgouveia, and E. Helmut. Seasonal and within-event dynamics of rainfall and throughfall chemistry in an open tropical rainforest in Rondonia, Brazil. Biogeochemistry 2007,86, 155-174.

29. [29] Kimmins, J. P. Some Statistical Aspects of Sampling Throughfall Precipitation in Nutrient Cycling Studies in British Columbian Coastal Forests. Ecology 1973,54, 1008-1019.

30. [30] Zimmermann, A. and W. Wilcke and H. Elsenbeer. Spatial and temporal patterns of throughfall quantity and quality in a tropical montane forest in Ecuador. Journal of hydrology 2007,343, 80-96.

31. [31] Draaijers, G. P. J. and R. V. Ek and W. Bleuten. Atmospheric deposition in complex forest landscapes. Boundary-layer Meteorology1994,69, 343-366.

32. [32] Michopoulos P., Bourletsikas A., Kaoukis K., Daskalakou E., Karetsos G., Kostakis M., Thomaidis N.S., Pasias I.N., Kaberi H., Iliakis S. The distribution and variability of heavy metals in a mountainous fir forest ecosystem in two hydrological years. Global Nest journal 2018,20, 188-197. 
33. [33] Schliemann S A, Bockheim J G. Influence of gap size on carbon and nitrogen biogeochemical cycling in Northern hardwood forests of Upper Peninsula. Plant Soil 2014, 377:323-335.

34. [34] Cornu, S., J. P. Ambrosi, Y. Lucas, and T. Desjardins. Origin and behaviour of dissolved chlorine and sodium in Brazilian Rainforest. Water Research 1998,32, 1151-1161.

35. [35] Mexico Cantú, S. I. and R. H. González. Interception loss, throughfall and stemflow chemistry in pine and oak forests in northeastern Mexico. Tree Physiology 2001, 21:1009.

36. [36] Säumel, I., I. Kotsyuk, M. Hölscher, C. Lenkereit, F. Weber, and I. Kowarik. How healthy is urban horticulture in high traffic areas? Trace metal concentrations in vegetable crops from plantings within inner city neighbourhoods in Berlin, Germany. Environmental Pollution 2012,165, 124.

37. [37] Arvik, J. H. and R. L. Zimdahl. Barriers to the Foliar Uptake of Lead1. Journal of Environmental Quality 1974,3, 369.

38. [38] Petty, W. H. and S. E. Lindberg. An intensive 1-month investigation of trace metal deposition and throughfall at a mountain spruce forest. Water Air \& Soil Pollution 1990, 53:213-226.

39. [39] Stachurski, A. and J. R. Zimka. Atmospheric input of elements to forest ecosystems: a method of estimation using artificial foliage placed above rain collectors. Environmental Pollution 2000,10, 345-356

40. [40] Szarek-ŁUkaszewska, G. Input of chemical elements to the forest ecosystem on the (Carpathian Foothills, S Poland)-An overview. Polish Journal of Ecology 1999,47, 191-213.

41. [41] Chinot, O. and S. Romain and P. M. Martin. Effects of root and foliar treatments with lead, cadmium, and copper on the uptake distribution and growth of radish plants. Environment International 1993.19, 393-404.

42. [42] Schreck, E., C. Laplanche, M. L. Guédard, J. J. Bessoule, A. Austruy, T. Xiong, Y. Foucault, and C. Dumat. Influence of fine process particles enriched with metals and metalloids on Lactuca sativa L. leaf fatty acid composition following air and/or soil-plant field exposure. Environmental Pollution 2013,179, 242-249.

43. [43] Tudoreanu, L., C. J. C. Phillips. Modeling Cadmium Uptake and Accumulation in Plants. Advances in Agronomy 2004,84:121-157.

44. [44] Levi, E., X. Dalschaert and J. B. M. Wilmer. Retention and absorption of foliar applied Cr. Plant E Soil 1973,38, 683-686.

45. [45] Sun, T. and M. Ma and D. Y. Wang. Interceptive characteristics of lead and cadmium in a representative forest ecosystem in mid-subtropical area in China. Acta Ecologica Sinica 2016, 36:218-225.

46. [46] Heinrichs, H., R. Mayer. The Role of Forest Vegetation in the Biogeochemical Cycle of Heavy Metals 1. Journal of Environmental Quality 1980,9, 226-231.

47. [47] Parker, G. G. Throughfall and Stemflow in the Forest Nutrient Cycle. Advance Ecological Research 1983,13, 57-133.

48. [48] Leininger, T. D. and W. E. Winner. Throughfall chemistry beneath Quercusrubra: atmospheric, foliar, and soil chemistry considerations. Canadian Journal of Forest Research 1988,18, 478-482.

49. [49] Ahmadshah, A., J. O. Rieley. Influence of tree canopies on the quantity of water and amount of chemical elements reaching the peat surface of a basin mire in the midlands of England. Journal of Ecology 1989,77, 357-370.

50. [50] Skřivan, P., J. Rusek, D., Fottová, M., Burian, L. Minařík. Factors affecting the content of heavy metals in bulk atmospheric precipitation, throughfall and stemflow in central Bohemia, Czech Republic. Water Air \& Soil Pollution 1995,85, 841-846.

51. [51] L, Gandois., E, tipping., C, dumat., A, probstl. Canopy influence on trace metal atmospheric input on forest ecosystems: Speciation on throughfall. Atmospheric Environment 2010,44, 824-833. 